Persp. Teol. 33 (2001) 163-193

\title{
O CAMINHO DA UNIDADE: ORAÇÃo PARA A CONVERSÃo
}

\author{
Juan A. Ruiz de Gopegui, SJ
}

\begin{abstract}
"A unidade que Cristo quer e pelos meios que ele quer"
\end{abstract}

A oração pela unidade da Igreja de Jesus Cristo no seio de uma Igreja dividida tem origens antigas. Em 1867, a primeira assembléia de bispos anglicanos em Lambeth, na introdução de suas resoluções, pede com insistência a oração pela unidade. Em 1894, o Papa Leão XIII encoraja a prática de um Oitavário de Oração no contexto de Pentecostes. Em 1935, o Padre Paul Couturier torna-se o advogado da "Semana universal de oração "pela unidade que Cristo quer e pelos meios que ele quer". Em 1958, o centro "Unidade cristã" de Lyon começa a preparar o tema para a Semana de Oração, em colaboração com a Comissão "Fé e Constituição" do Conselho Mundial de Igrejas. Em 1964, o Concílio Vaticano II sublinha, no documento sobre o Ecumenismo, que a oração é a alma do movimento ecumênico e encoraja a prática da Semana de Oração. Em 1966, a Comissão "Fé e Constituição" e o Secretariado para a Unidade dos Cristãos da igreja católica (o atual Conselho Pontifício para Promoção da Unidade dos Cristãos) decidem preparar em conjunto o texto para a Semana de Oração de cada ano. E, em 1968, pela primeira vez, a "Oração pela unidade" é celebrada com base nos textos elaborados por esses organismos'.

\footnotetext{
${ }^{1}$ Aparece aqui um progresso na forma de conceber a oração pela unidade na mentalidade da Igreja católica. Nos começos, na mentalidade dos católicos romanos, se orava para que os "hereges" voltassem ao seio da Igreja. Em 1910, a Igreja romana rejeitava
} 
A expressão do Pe. Couturier - "a unidade que Cristo quer e pelos meios que ele quer" - tornou-se uma espécie de lema constantemente lembrado e parafraseado em encontros e documentos ecumênicos. Orar pela unidade implica pedir o dom de discernir que unidade Cristo quer e por que meios ele a quer.

Isso é um apelo à escuta da Palavra de Deus e ao discernimento. É preciso afirmar, por um lado, que a oração cristã é, em primeiro lugar, escuta da Palavra de Deus, revelada em Cristo. Só a partir dessa palavra discernida e acolhida pode nascer a súplica que convêm. Por outro lado, é preciso lembrar que a oração cristã não tem como objetivo dobrar a vontade de Deus aos desejos humanos, mas abrir os anseios humanos à vontade de Deus. Ninguém mais do que o Cristo quer a unidade da sua Igreja e se ela não se realiza é justo pensar que as igrejas põem obstáculos à acolhida desse dom.

Ao implorar a unidade, as igrejas estão pedindo insistentemente a própria conversão: conversão à universalidade da missão do Cristo, conversão ecumênica, portanto. Ecumene ${ }^{2}$ (gr. oikoumene), termo freqüente na Bíblia, designa a terra habitada, o universo inteiro, ao qual é oferecida a salvação do Cristo. Ecumenismo é o oposto de proselitismo. Paulo o tinha compreendido muito bem. As igrejas devem ter em mira a salvação de todo ser humano, antes que a cobiça de aumentar as suas fileiras.

“É nesta perspectiva que o problema da unidade da Igreja é posto corretamente. A unidade é o corolário da ecumenicidade ou missão universal, seu instrumento indispensável" ${ }^{\prime 3}$. Jesus ora para que seus discípulos sejam um, a fim de que o mundo creia. A Igreja de Jesus Cristo, como se afirma nos recentes documentos ecumênicos, só pode ser una.

Quando se fala em igrejas, no plural, a expressão deve ser entendida como referência às diversas comunidades eclesiais, nas quais se torna presente a única Igreja de Cristo: as igrejas particulares ou

\footnotetext{
o convite a colaborar no movimento "Fé e Constituição". Em 1928, a Encíclica Mortalium animos fundamentava esta decisão com estas palavras: "É evidente que nem a Sé Apostólica pode participar de forma alguma nessa Conferência, nem se pode autorizar aos católicos que apoiem tais propostas ou nelas participem. Se o fizerem, estariam dando valor a uma falsa religião cristã, radicalmente distinta da única Igreja", AAS 20 (1928) p.11. Certamente essa mudança de orientação na forma de conceber a oração pela unidade é já fruto da oração "pela unidade que Cristo quer e pelos meios que ele quer".

2 Preferimos usar o neologismo "Ecumene", mais comum em escritos teológicos, do que o termo usado no Aurélio Século XXI: "ecúmeno".

${ }^{3}$ G. CASALIS, "CEcuménisme", in Encyclopaedia Universalis, Vol. 11, Paris 1977², p. 1087, atualizado na edição eletrônica.
} 
dioceses, da mesma confissão, ou as diversas confissões cristãs. A divisão da única Igreja de Jesus Cristo é que toma ambígua a expressão.

A recente declaração, Dominus Jesus, da Congregação para a Doutrina da Fé parece negar o título de "igrejas irmãs" às Comunidades da Reforma, outorgando-lhes apenas o título de Comunidades eclesiais". Uma exegese acurada, porém, dos Documentos Conciliares não justifica esta interpretação restritiva das formulações dos próprios textos e dos progressos ecumênicos posteriores ${ }^{5}$. Na encíclica Ut unum sint, João Paulo II afirma:

Com efeito, os elementos de santificação e de verdade prescntes nas outras Comunidades cristãs, em grau variável duma para outra, constituem a base objetiva da comunhão, ainda imperfeita, que existe entre elas e a Igreja Católica. Na medida em que tais elementos se encontram nas outras Comunidades cristãs, a única Igreja de Cristo tem nelas uma presença operante ${ }^{6}$.

\section{O apelo de João Paulo à conversão}

O Papa João Paulo II, na sua carta apostólica, preparatória do ano jubilar, Novo Millenio ineunte, afirma:

Entre as süplicas mais ardentes desta hora excepcional que é o aproximar-se do novo Milènio, a Igreja implora do Senhor que creş̧a a unidade entre todos os cristãos das diversas Confissóes até à obtenção da plena comunhão. Faço votos de que o Jubileu seja a ocasiāo propícia para uma frutuosa colaboração visando colocar em comum as muitas coisas que nos unem, e que são seguramente mais do que aquelas que nos dividem. Muito ajudaria nesta perspectiva se, no respeito dos programas das diversas Igrejas e Comunidades, se alcançassem acordos ecumênicos na preparação e celebração do Jubileu: este ganharia assim mais força ainda, testemunhando ao mundo a decidida vontade de todos os discipulos de Cristo de conseguirem o mais rapidamente possivel a plena unidade, na certeza de que "a Deus nada é impossivel" ?.

\footnotetext{
4 "As Comunidades eclesiais, invés, que não conservaram um válido episcopado e a genuína e íntegra substância do mistério eucarístico, não são Igrejas em sentido próprio", Dominus lesus $\mathrm{n}^{\circ} 17$.

${ }_{5}$ Cf. P. NEUNER, "Belastungsprobe für die Ökumene. Anmerkungen zum Kirchenverständnis in einem Dokument der Glaubenskongregation", Stimmen der Zeit 218 (2000) 723-737. Condensado em "Prueba de fuego del ecumenismo. Observaciones sobre la concepción de la Iglesia en un documento de la Congregación de la Fe", Selecciones de Teologia, $40 / \mathrm{n}^{\circ} 158$ (2001) 99-110.

'Ut unum sint, $\mathrm{n}^{\circ} 11$

7 Carta Apostólica Tertio millentio adveniente do sumo Pontífice joão Paulo II ao episcopado ao clero e aos fiéis sobre a preparação para o jubileu do ano $2000, \mathrm{n}^{\circ} 16$.
} 
Que esta súplica seja um pedido de conversão, o Papa o mostrava na mesma carta apostólica.

Entre os pecados que requerem maior empenho de penitência e conversão, devem certamente ser incluídos os que prejudicaram a unidade querida por Deus para o seu Povo. Ao longo dos mil anos que estão para se concluir, mais ainda do que no primeiro milênio, a comunhão eclesial, «algumas vezes não sem culpa dos homens dum e doutro lado", conheceu dolorosas lacerações que contradizem abertamente a vontade de Cristo e são escândalo para o mundo. Tais pecados do passado fazem sentir ainda, infelizmente, o seu peso e permanecem como tentações igualmente no presente. É necessário emendar-se, invocando intensamente o perdão de Cristo ${ }^{8}$.

Os próprios textos propostos para as celebrações da Semana de Oração mostram esse caráter penitencial da súplica ecumênica: são um pedido de conversão, mediante a escuta da Palavra do Senhor.

No centro da celebração proposta para a Semana de Oração pela Unidade 2001, está o tema para a semana escolhido de João 14, 6, "Eu sou o caminho, a verdade e a vida". "Eu sou o caminho", diz Jesus. Isto significa que Cristo não é somente a fonte e a meta da unidade, mas também Aquele que acompanha e guia a sua Igreja em sua caminhada e seu crescimento em direção à unidade 9 .

A Semana de Oração pela unidade é talvez a iniciativa ecumênica melhor aceita nas diversas confissões cristãs. Poderia, contudo, cair em mero formalismo se ficasse reduzida a um tempo de oração, realizado uma vez por ano. O próprio texto proposto para este ano recorda:

A busca da unidade dos cristãos não se limita a uma semana por ano. Nós os encorajamos pois, a considerar este material como um convite a encontrar outras ocasiões, ao longo do ano, para expressar o grau de comunhão que as Igrejas têm já atingido e para oração conjunta em busca da plena unidade desejada por Cristo ${ }^{10}$.

Esta prática deveria levar o povo cristão a um espírito permanente de oração em busca da conversão querida por Cristo para que sua Igreja caminhe para a unidade. Isto certamente está longe de ter acontecido. Se o Concílio Vaticano II suscitou e alimentou grandes esperanças ecumênicas, atualmente, passados mais de três decênios, a sensação mais freqüente é de desencanto.

\footnotetext{
${ }^{8}$ Ibidem, $\mathrm{n}^{\circ} 34$.

9 Tomamos o Texto pela Internet do site do Vaticano: A Cúria Romana, Conselho Pontifício para a Promoção da Unidade dos Cristãos. Introdução à celebração ecumênica. http://www. rc_pc_chrstuni_doc_20001215_prayer-2001_po.htm. 10 Ibidem.
} 


\section{Dois lugares ecumênicos exemplares}

Há, contudo, ao menos, dois lugares exemplares, nos quais o movimento ecumênico suscitado pelo Concílio cresceu consideravelmente. O primeiro é o dos diálogos interconfessionais, que, sobretudo a partir do Concílio, tem se realizado entre teólogos, pastores, muitos deles bispos, e representantes dos organismos oficiais das diversas igrejas, inclusive do Vaticano. Fruto deles são diversos documentos mostrando acordo em pontos fundamentais de doutrina, controvertidos durante séculos e considerados responsáveis pelas divisões.

O segundo lugar é a vida monástica, redescoberta como lugar privilegiado de conversão permanente e de oração pela unidade da Igreja de Cristo. Tenho nas mãos um livro de título sugestivo, La vie monastique, lieu ocumenique. Au cour de l'Église de communion, escrito por uma monja. Ela nos conta que, quando em 1965, em Taizé, ouviu da amiga luterana Ilse Friedeberg a alegria que sentira ao ver que o Concilio Vaticano II reconhecera oficialmente que a Igreja, santa por graça, tinha contudo que se purificar constantemente, compreendeu que o seu próximo engajamento na vida monástica, como vida de conversão permanente, seria solidário da conversão da Igreja da qual ela é membro e de todas as igrejas que compõem a única Igreja de Cristo ${ }^{11}$.

Estes dois lugares mostram que, quando os cristãos se engajam no movimento ecumênico, anterior certamente ao Vaticano II, mas acolhido e incentivado na igreja católica romana por esse Concílio, os frutos aparecem. Baste recordar o recente acordo oficial luterano-católico em que se afirma:

Com base nas concordâncias alcançadas na Declaração Conjunta sobre a Doutrina da Justificação (DC), a Federação Luterana Mundial e a Igreja Católica declaram juntas: "A compreensão da doutrina da justificação exposta nesta Declaração mostra que entre luteranos e católicos há um consenso em verdades básicas da doutrina da justificação" (DC 40). Com base neste consenso a Federação Luterana Mundial e a Igreja Católica declaram juntas: "A doutrina das Igrejas Luteranas apresentada nesta Declaração não é atingida pelas condenações do Conciltio de Trento. As condenações expressas nos escritos confessionais luteranos não se aplicam à doutrina da Igreja Católica romana apresentada nesta Declaração" (DC 41) ${ }^{12}$.

\footnotetext{
${ }^{11}$ M. SIMON, La vie monastique, lieu œecumenique: Au cœur de l'Église de communion, Paris: Cerf, 1997.

${ }_{12}$ Posicionamento oficial conjunto da federação luterana mundial e da igreja católica, $\mathrm{n}^{\circ}$ 1. Site do Vaticano: A Cúria Romana, Conselho Pontifício para a Promoção da Unidade dos Cristãos, http://www.vatican va.
} 
Que longo caminho de paciente diálogo, realizado em espírito de oração e conversão não foi necessário para chegar a afirmações como essas! Só assim pode ser recebido o dom da compreensão do ponto de vista do interlocutor, visto até então, como oposto!

Quanto à vida monástica, a obra de Monique Simon, apresenta ricas experiências de vida de oração, em abertura ecumênica, tanto na igreja católica romana, como nas igrejas ortodoxas, e nas igrejas nascidas da Reforma, nas quais se viu recentemente ressurgir o monaquismo. É significativo que a ressurgimento da vida monástica, em algumas destas igrejas, vá junto com a redescoberta da Igreja como corpo de Cristo e da vida litúrgica, fonte e cume, como disse o Concîlio, de toda a vida cristã.

Diaconisas de Reuilly, no Cameroun, o mosteiro protestante das irmãs de Reuillly na Noruega, as irmãs de Granchamp, na igreja reformada da Suíça, as irmãs de Pomeyrol, de estilo franciscano na França, as irmãs da Ordo Pacis, da igreja luterana, Taizé qualificado pela autora de "parábola de comunhão", a comunidade interconfessional de Bosse, a fraternidade ecumênica de Étoy, a comunidade católica cisterciense La Paix-Dieu, à qual Monique Simon pertence, săo uma profecia viva da unidade que Cristo quer e que é esperada em atitude orante pelo caminho que ele quiser. Cumpre-se nesses belos testemunhos o que diz João Paulo II:

A comunhão na oração induz a ver com olhos novos a Igreja e o cristianismo. Com efeito, não se deve esquecer que o Senhor implorou do Pai a unidade dos seus discípulos, para que servisse de testemunho à sua missão e o mundo pudesse acreditar que o Pai $O$ tinha enviado (cf. Jo 17,21$)^{13}$.

Ver com novos olhos a Igreja e o cristianismo, supõe uma conversão radical, fruto da oração. Enraizada na escuta contemplativa da Palavra de Deus, atenta à Tradição da Igreja de Jesus Cristo, para além das estreitezas das tradiçōes particulares, na procura de uma vida comum e dócil ao Espírito, a vida monástica é para a Igreja lugar exemplar da koinonia que a vida em Cristo deve gerar entre todos os cristãos e entre as igrejas.

\section{Um caminho de conversão para as igrejas}

Estes dois lugares ecumênicos podem inspirar um caminho pastoral que deve ser estendido a todo povo cristão. Sem isso não será possível avançar consideravelmente na direção da unidade. A comu-

"ut unum $\sin t, \mathrm{n}^{\circ} 23$. 
nhão das igrejas não poderá ser decretada do alto. Essa via provocaria novas divisões. Por isso, na Carta apostólica do encerramento do Ano Jubilar, o Papa, após ter lembrado os gestos de caráter ecumênico que tiveram lugar ao longo desse ano, afirma:

O caminho ecumênico continua certamente fatigoso, e talvez longo, mas anima-nos a esperança de sermos guiados pela presença do Ressuscitado e pela força inexaurivel do seu Espirito, capaz de surpresas sempre novas ${ }^{14}$.

Para "não cair em fantasias milenaristas" e sabendo que "o cristianismo é religiāo entranhada na história"15" é razoável pensar que essas surpresas devam ser preparadas "pela força do Espírito", estendendo ao povo cristão a atitude de conversão que, nos dois lugares exemplares evocados acima, estão dando frutos de diálogo ecumênico. O que este artigo propõe à reflexão pastoral das igrejas - em forma de ensaio e sem ilusões nem pretensōes proféticas, quase à maneira de "um sonho"16 que deverá percorrer longo caminho antes de tornar-se realidade - é a urgência de retomar com todo o povo cristão a atitude de acolhida do sopro do Espírito que permitiu enxergar o Concilio Vaticano II como "novo Pentecostes", abrindo caminhos surpreendentes na direção da unidade da Igreja de Jesus Cristo. Se a voz profética de Paulo VI afirmava ser o ecumenismo a alma do Concilio, não é de estranhar que o desencanto de muitos com a caminhada ecumênica esteja acompanhado da sensação de um retrocesso pastoral, em grandes setores da Igreja, em relação à renovação conciliar.

Que esta sensação não seja fantasiosa e que ela preocupe também pessoas com uma responsabilidade especial na fidelidade à fé apostólica, o mostram as palav ras com que o Cardeal Martini terminava uma intervenção no Sínodo dos bispos europeus de 1999.

Nos sentimos levados a interrogar-nos se, quarenta anos após o começo do Vaticano II, não esteja madurando aos poucos, para o próximo decênio, a consciência da utilidade e quase da necessidade de

\footnotetext{
is Carta Apostólica Noro millennio ineunte do Sumo Pontífice João Paulo Il ao episcopado, ao clero e aos fiéis no termo do grande jubileu do ano 2000; Belo Horizonte: Projeto Pastoral "Construir a esperança", 2001, $\mathrm{n}$ " 12.

"São expressões da mesma Carta Apostólica, n" 5.

it A expressão me é sugerida por uma intervenção do cardeal Martini, arcebispo de Milão, no Sínodo dos bispos europeus, em 7.10.99. Evocando a expressão I had a dream do saudoso cardeal Basil Hume, arcebispo de Westminster, Martini dizia: "Também eu, nestes dias, escutando as intervenções, tive um sonho, mais ainda, vários sonhos". Um deles girava em torno "ao aprofundamento e desenvolvimento da eclesiologia de comunhão do Vaticano II", que, como se verá ao longo deste artigo é o ponto nevrálgico para o progresso do ecumenismo. Cf. "Mis três sueños", Selecciones de Teologia, $39 / \mathrm{n}^{\mathrm{v}} 154$ (2000) $116 \mathrm{~s}$.
} 
confronto colegial e autorizado entre todos os bispos, sobre alguns dos temas medulares surgidos nestes quatro decênios. Aumenta a sensaf̧ão de como seria belo e útil para os bispos de hoje e de amanhä, numa Igreja agora cada vez más diversificada nas suas linguagens, repetir aquela experiência de comunhäo, de colegialidade e de Espirito Santo que seus predecessores desenvolveram no Vaticano II e que hoje somente é memória viva a partir de contados testemunhos. Roguemos ao Senhor, por intercessão de Maria, que estava com os apóstolos no Cenáculo, que nos ilumine para discernir se, como e quando, nossos sonhos, podem converter-se em realidade ${ }^{17}$.

Tratando-se de uma proposta de conversão, no interior de um diálogo ecumênico, a perspectiva deste ensaio será necessariamente a da igreja católica de que faz parte o autor. Conversão ou metanoia (em grego) diz mudança de atitude, orientada para a reconciliação com Deus e com os outros. Sem esta atitude, o diálogo seria impossível. A igreja católica é obrigada a reconhecer que nem sempre seus membros a tiveram. Mas o problema não é só do passado. Se nos sentimos incomodados com a frase de Bossuet aos protestantes: "Eu os convencerei com argumentos invencíveis ${ }^{\prime \prime} 18$, quem poderia assegurar que muitos católicos não partilhem hoje convicções parecidas? A oração pela unidade não será ainda, para muitos, oração para que os outros se convertam à "nossa igreja"?

Por outro lado não faltaram no passado, mesmo nos tempos da grande separação, belos exemplos em sentido oposto. $O$ papa Adriano VI, nos dias tormentosos da Reforma protestante, no seu brevíssimo pontificado (1522-1523), tentou encaminhar a igreja católica a uma reforma que julgava necessária. Eis o texto que fez ler ao núncio Chieregati, na dieta de Nuremberg, no dia 25 de novembro de 1522 :

Reconhecemos livremente que Deus permitiu esta perseguição da Igreja por causa dos pecados dos homens e particularmente dos padres $e$ dos prelados $[. .$.$\rfloor Sabemos que mesmo na Santa Sé, desde faz anos,$ vem-se cometendo muitas abominações: abuso das coisas santas, transgressões dos mandamentos de tal sorte que tudo se tornou escândalo. Não há por que se admirar de que a doença tenha descido da cabeça aos membros, dos papas aos prelados. Todos nós, prelados e eclesiásticos, nos temos desviado do caminho da justiça. Há já muito tempo que ninguém faz o bem, e é por isto que todos nós devemos adorar Deus e humilhar-nos diante dele; cada um de nós deve examinar-se a si mesmo com mais rigor do que será julgado por Deus no dia de sua cólera. Em consequiência, prometerás em nosso nome que nós poremos todo nosso empenho em começar a melhorar a corte de Roma da qual

${ }^{17}$ Cf. nota anterior.

${ }^{18}$ Citada por B. SESBOÜE, Pour une théologie acuménique, Paris: Cerf 1990. 
talvez tenha provindo todo o mal; é dela que sairá a cura, como dela veio a enfermidade ${ }^{19}$.

Em primeiro lugar é necessária uma conversão afetiva. Acolher o irmão de confissão diferente. Esta atitude está crescendo certamente. Mais difícil é a conversão da mentalidade. As mentalidades têm raízes profundas: passam pelos longos e marcantes anos da formação, chegam até o subconsciente e penetram no terreno de sentimentos ancestrais que ultrapassam gerações. Não é raro que pessoas e comunidades que sinceramente procuram a unidade dos cristãos e oram por ela, com as suas formas concretas de viver a fé - e digamos também o ministério - ponham barreiras quase intransponiveis ao avanço da caminhada ecumênica ${ }^{20}$.

Este ensaio quer esboçar, brevemente, alguns pontos nevrálgicos que merecem a atenção de uma ação pastoral que pretenda levar a sério o apelo do Concilio Vaticano Il a uma renovação, capaz de encurtar os caminhos de volta à unidade da Igreja de lesus Cristo. $O$ apelo a uma reforma que - na prática concreta da vida cristã e não apenas na teoria - ponha a obediência à Palavra de Deus como fundamento e objetivo da obediência à instituição eclesiástica e aos seus ministros. Humildemente devemos reconhecer que se foram necessários quatro séculos para que a Igreja enfrentasse sem medo um projeto de aggionarmento - que em muitos pontos coincidia com o ideal da Reforma protestante - é porque o "pecado comum" da divisão, que então se originara, tinha raízes profundas. Elas explicam, também, as resistências, os medos e os recuos freqüentes em relação à renovação conciliar.

\section{Luzes e sombras da Reforma e da Contra-Reforma}

O católico comum, educado para ver o Protesto da Reforma como algo negativo, deve ser reeducado para considerar o que nele havia de positivo e, portanto, como suscitado pelo Espírito. A divisão da Igreja que se seguiu, evidentemente, não pode ser atribuída ao Espírito. Só pode ser consequêencia do pecado e revela a sua presença, que não

19 O. de la BROSSE, H. HOLSTEIN, C. LEFEBVRE, Latran $V$ et Trente, t. 1, Paris: Orante, 1975, pp. 168-169. Citado por B. SESBOÜÉ, Op. cit., p.30.

20 Talvez por aqui possa explicar-se a ambigüidade com que o pontificado de João Paulo II se apresenta ao olhar de muitos cristãos. G. CASALIS, após mencionar notáveis gestos ecumênicos do Papa, acrescenta: "Mas o retorno de uma certa papolatria e o vento de restauração que sopra do Vaticano em matéria disciplinar, moral e doutrinal inquietam numerosos cristãos e comunidades não católicas." Certamente também comunidades católicas. Cf. Op. cit., na edição eletrônica. 
deve ser confinada de forma simplista num dos lados da contenda. A divisão mostra que ao ouvir certos apelos do Espírito, por insuficiente discernimento, no momento de pô-los em prática, podem infiltrar-se na ação humana motivações, impulsos e desejos que não procedem puramente da primeira inspiração do Espírito ${ }^{21}$.

Quem duvidaria que o ideal luterano de reencontrar a verdadeira Tradição apostólica, por uma volta ao Evangelho, fosse um apelo do Espírito? Mas se desse legítimo desejo, se segue a ruptura da unidade eclesial e o enfraquecimento de um dos instrumentos deixados por Cristo para serviço da Tradição - a sucessão no Colégio Apostólico com o sinal da unidade de Pedro - pode se suspeitar que "pensamento humanos" 22 se misturem ao apelo primeiro do Espírito.

Do outro lado, se a certeza da sucessão apostólica, pela obediência ao Colégio Apostólico, sob o sinal da unidade do sucessor de Pedro, cria tal segurança de estar na verdadeira tradição apostólica, que leva a desconhecer ou não dar a suficiente importância às legítimas aspirações que postulavam maior fidelidade à doutrina apostólica, manifesta-se aí também um insuficiente discernimento das inspirações do Espírito.

Dito de forma muito simples, é óbvio que a obediência à instituição eclesiástica está a serviço da obediência à Palavra de Deus. Mas é igualmente certo que, para obedecer à Palavra de Deus, não podem ser desprezados os meios deixados pelo próprio Senhor para serviço da Palavra.

Os repetidos pedidos de perdão do Papa em diversos encontros com membros de outras confissões cristãs mostram que a Igreja atualmente reconhece a própria culpa de insuficiente discernimento dos caminhos do Espírito. Mas pedir perdão pelo passado, como aparece também em alguns desses pronunciamentos, só tem sentido enquanto esse gesto manifesta o desejo atual de evitar atitudes semelhantes e de reparar os danos que elas causaram e que, em muitos dos seus aspectos, podem perdurar. Foi o Concilio Vaticano Il que marcou uma mudança de rumo da igreja católica romana em relação ao pecado da ruptura da unidade da Igreja de Jesus Cristo.

\footnotetext{
21 Poder-se-iam aplicar aos grupos e comunidades as regras que Inácio de Loyola oferece à pessoa que, através dos "Exercícios Espirituais", procura encontrar a vontade de Deus para sua vida.

${ }^{22} \mathrm{Cf}$. Mc 8, 33. Certamente é Deus que inspira a Pedro a confissão messiânica (cf. Mt 16,17), mas isso não impede que outros pensamentos não provenientes de Deus se misturem ao conteúdo de sua confissão.
} 
Também das culpas contra a unidade, vale o testemunho de são João: "Se dissermos que não temos pecado, fazemo-lo mentiroso e a sua palavra não está em nós (1Jo l,10). Por isso, pedimos humildemente perdão a Deus, e aos irmãos separados, assim como também nós perdoamos àqueles que nos ofenderam ${ }^{23}$.

O povo cristão deve ser educado para a procura constante da Tradição apostólica, com senso critico e sensibilidade ecumênica que o leve a perceber as deformações do "catolicismo romano" que, de alguma forma, perduram até hoje ou mesmo ressurgem com nova força, de tempos em tempos, avolumando os obstáculos no caminho para a unidade da Igreja de Jesus Cristo.

O ponto de partida para isto é indicado pelo Concílio: o reconhecimento da santidade que existe nas igrejas cristãs separadas:

Por outro lado, é mister que os católicos reconheçam com alegria e estimem os bens verdadeiramente cristãos, oriundos do patrimônio comum, que se encontram nos irmãos de nós separados.

E digno e salutar reconhecer as riquezas de Cristo e as obras de virtude na vida dos outros que dão testemunho de Cristo, às vezes, até à efusão do sangue. Deus é, com efeito, sempre admirável e digno de admiração em suas obras.

Nem se deve esquecer que tudo o que a graça do Espírito Santo realiza nos irmãos separados pode também contribuir para a nossa edificação. Tudo o que é verdadeiramente cristão jamais se opõe aos bens genuinos da fé, antes sempre pode fazer com que mais perfeitamente se compreenda o próprio mistério de Cristo e da Igreja ${ }^{24}$.

Era de esperar que este ponto de partida do reconhecimento da santidade, e, portanto, da ação do Espírito, tivesse como fruto o reconhecimento de muitos dos instrumentos do Espírito para a santidade da Igreja, abrindo caminhos para um reconhecimento e uma reconciliação dos ministérios. Nos grupos interconfessionais de diálogo ecumênico isto foi acontecendo, como fruto da atitude de conversão que permeou o diálogo. Veja-se, por exemplo, este texto do documento freqüentemente citado com a sigla BEM:

A fim de chegarem ao reconhecimento mútuo dos ministérios, as diversas igrejas têm de percorrer diferentes etapas, por exemplo:

(a) As igrejas que conservaram a sucessão episcopal deverão reconhecer o contelido apostólico do ministério ordenado, existente nas igrejas

${ }^{23}$ Unitatis Redintegratio, $\mathrm{n}^{\circ} 7$

24 Ibidem, $\mathrm{n}^{\circ} 4$. 
que não conservaram essa sucessão, bem como a existência nestas igrejas de um ministério da episkopê sob variadas formas.

(b) As igrejas sem a sucessão episcopal, que vivem na continuidade fiel com a fé e a missão apostólicas, têm um ministério da Palavra e dos sacramentos evidenciado na sua fé, prática e vida. Tais igrejas devem dar-se conta de que a continuidade com a Igreja dos apóstolos encontra expressão profunda na sucessão da imposição das mãos pelos bispos, e de que, mesmo não estando elas privadas da continuidade na tradição apostólica, este sinal fortalecerá e aprofundará essa continuidade. Elas terão que redescobrir o sinal da sucessão episcopal 25 .

O ponto que possibilita o diálogo, na difícil questão da "sucessão apostólica", é a distinção (não separação) entre "tradição apostólica" e "sucessão no ministério apostólico". Se é verdade que há um grande caminho a percorrer até chegar a um consenso doutrinal, neste ponto crucial do caminho da unidade, não há dúvida que se abrem com essa perspectiva fecundas possibilidades.

B. Sesboüé, membro do grupo de Dombes, escreve:

Para exprimir nosso reconhecimento dos ministérios reformados inspiramo-nos num texto do Vaticano II que descreve a vida cristã e eclesial das comunidades separadas de nós. Mas nós tiramos conclusões mais explícitas em relação ao ministério. A realidade de uma vida eclesial e sacramental supõe, de fato, um "real" ministério, mesmo se este não responde a todas as exigências católicas. Saiamos do tudo ou nada: não reconhecer "a plenitude perfeitamente significada do ministério" não equivale a não reconhecer "a consistência real" deste ministério. O termo impreciso foi escolhido adrede. Deus tem dado um ministério a comunidades que a ruptura com a igreja católica não privava de uma sucessão apostólica na fé.

Mais adiante acrescenta:

Como passar da «consistência real» para a "plenitude»? Não será dando voltas estéreis (ergotant) sobre o passado, tentando pesar uma consistência que é o segredo de Deus. Será restabelecendo uma «junção", uma reunificação, entre este ministério suscitado pelo Espírito e o sinal normal da sucessão episcopal, em nome do pressuposto doutrinal, anteriormente desenvolvido: "realidade e sinal se chamam mutuamente no Mistério da Igreja». Um discernimento eclesial é pois proposto aos bispos católicos: podem eles reconhecer o ministério reformado dando-lhe o sinal que the falta e o constituiria numa plenitude visivel? ... Isto seria em definitivo um ato de obediencia ao Espirito". O sinal

${ }^{25}$ FÉ E CONSTITUIÇÃO. CONSELHO MUNDIAL DAS IGREJAS, Batismo, eucaristia, ministério: convergência da fé. Rio de Janeiro: CONIC-CEDI, 1983, $\mathrm{n}^{\circ} 53$. 
proposto poderia ser a imposição mútua das mãos não como "reordenação" mas como sinal de reconhecimento e de reconciliaçäo ${ }^{26}$.

Esta foi uma proposta corajosa, lançada pelo grupo de Dombes, quase "como uma garrafa lançada ao mar", diz Sesboüé. Ela só poderia ser feita num primeiro momento em âmbito local, engajando do lado católico a presença de um ou mais bispos, em comunidades em que uma caminhada ecumênica tiver permitido chegar a um grau suficiente de fé comum e de conversão espiritual e nas quais haja problemas urgentes de pastoral, como por exemplo numerosos lares mistos. "Assim, de um para outro, os lugares de reconciliação ecumênica avançada, poderiam se multiplicar e preparar a unidade geral futura"27.

É claro que por aqui se indica um possível caminho para o futuro, e não uma proposta passível de ser posta em prática de imediato. Requerer-se-ia como pressuposto que tivesse sido desenvolvida a prática da eclesiologia de comunhão do Vaticano II, com uma crescente descentralização em relação a um governo central e uma vivência aprofundada da colegialidade episcopal em face de uma Igreja cada vez mais diversificada em suas linguagens, para usar a expressão do card. Martini, anteriormente citada $^{28}$.

A proposta parecerá a muitos temerária e, à primeira vista, sem fundamento teológico. Dentro dos parâmetros da teologia comum do ministério - de um e outro lado do diálogo ecumênico - dificilmente se chegaria a uma conclusão semelhante. Mas escutemos o que diz a respeito dela um membro do grupo de Dombes, o eminente teólogo católico Sesboüé,:

Os membros do grupo somente ousaram fazer tal proposta após uma lenta caminhada. Eles tentaram viver uma atitude de mútua conversão $e$ de conversão comum a Jesus Cristo $e$, assim, experimentaram a fecundidade desta atitude. Mas descobriram, ao mesmo tempo, que esta conversão não podia limitar-se apenas a algumas pessoas, mas devia engajar as confissões eclesiais, enquanto tais, e traduzir-se em gestos concretos. Eles são conscientes de que a audácia de sua propostas exige mais do que uma adaptação do olhar para acolher com benevolencia aquilo que pode chocar num primeiro momento. Exige de uma parte e de outra um questionamento crucificante a respeito de si mesmo. Para nós seria suficiente, portanto, que o leitor não preparado, mas sem preconceitos, dissesse diante da hipótese que propomos: "É

${ }^{26}$ Cf. B. SESBOÜÉ, Pour une théologie cocuménique, Paris: Cerf 1990, pp. 288-311; especialmente pp. 305-307.

${ }^{27}$ GROUPE DE DOMBES, Pour une réconciliation des ministères: Commentaire, p. 55, citado por B. SESBOÜÉ, Op. cit. p. 310 .

${ }^{28}$ Cf. Nota 16. 
demasiado dificil aceitá-la; exige um sacrificio considerável; será ele verdadeiramente justificado? Dêem-me um tempo para pensar. Mas se o caminho da unidade devesse passar por aí, eu não me oporia"29.

Não pode ser o objetivo deste artigo discutir pormenorizadamente os argumentos teológicos que justificariam uma proposta dessa natureza, num tema tão complexo como o do ministério. $O$ que o artigo quer mostrar é que para chegar a propostas que conduzam ao reconhecimento da unidade da Igreja de Jesus Cristo, é necessário percorrer longos caminhos de conversão e de diálogo. Somente uma teologia repensada e confrontada no interior de um diálogo real com a teologia de grupos de outra confissão cristã, reconhecendo neles, com o Concílio, os reais frutos de santidade, se pode chegar ao conseqüente reconhecimento de um "real" ministério a serviço dessa santidade. Chega um momento em que o diálogo, para caminhar, deve estender-se, através de uma pedagogia adequada, a todo o povo cristão, como o próprio documento propõe.

Diríamos mais: se grupos de teólogos, empenhados no ecumenismo, chegam a propostas dessa envergadura é porque viveram a sua fé e despertaram para o ideal ecumênico no seio de uma Igreja que procura toda ela viver em espírito de renovação e de diálogo. E significativo que os grandes arautos do ecumenismo sejam atualmente pessoas que viveram os tempos renovadores do Concílio e depois, pacientemente e não raramente de maneira "crucificante", persistiram, durante décadas, num caminho em que experimentaram a ação do Espírito.

Urge, portanto, que a procura da unidade da Igreja de Jesus Cristo se torne preocupação de todo o povo cristão. Ela não pode ser apenas ideal de um grupo de especialistas ou de pastores. Por outro lado, a experiência está mostrando que o estilo dos pastores, em grande parte, corresponde ao estilo das comunidades em que se formam. Não é difícil observar na atualidade que o retrocesso, em grandes setores do povo cristão, com relação aos ideais da renovação conciliar, e a volta às formas de catolicismo legitimamente criticadas pela Reforma, estão acompanhados do surgimento de membros do clero com as mesmas características. Fenômenos semelhantes podem ser observados em algumas das igrejas nascidas da reforma protestante.

Uma atitude de conversão que se estenda a todo o povo cristão é necessária para que propostas viáveis para uma reconciliação ecumênica possam abrir-se caminho, tanto no âmbito dos fiéis, como dos teólogos, dos pastores e dos organismos que zelam pela ortodoxia da fé. Voltando à proposta apresentada pelo grupo de Dombes para a recon-

${ }^{2 y}$ B. SESBOÜÉ, Op. cit. p. 302. 
ciliação dos ministérios, merece ser recordado o seguinte Comentário do grupo à proposta:

\begin{abstract}
Quem se recusasse a entrar nesta perspectiva de reconciliação concreta não poderia compreender de que se trata aqui; suas objeções, mesmo teológicas, o exporiam a ser julgado, caso não procurasse engajar-se num processo de conversão do seu coração e da sun mentalidade. Pelo contrário, toda objeção manifestada no interior desta atitude de "conversão» será positiva para a busca de uma solução, capaz de melhorar ou ultrapassar nossa proposta ${ }^{30}$.
\end{abstract}

É nesse clima de conversão, capaz de questionar conviç̧ões e idéias teológicas enraizadas em mentalidades de pessoas e de grupos, tecidas durante séculos de separação e de discórdia, que propostas como estas podem ser julgadas, melhoradas ou ultrapassadas pela ação do Espírito, que age nos corações que buscam ardentemente redescobrir a unidade da Igreja de Jesus Cristo. Imprescindivel, antes de qualquer confronto doutrinal, é a atitude incondicional de conversão, que não pode ser facilmente pressuposta, porque a história mostra como são complexas e intrincadas as astúcias do subconsciente de indivíduos e comunidades na busca de autojustificação. Eis o testemunho exemplar de J.-M. Tillard, vice-presidente de Fé e Constituição do Conselho Ecumênico das Igrejas, consultor do Secretariado para a Unidade dos Cristãos (Vaticano) e membro de numerosas comissões ecumênicas:

O diálogo ecumênico é o instrumento do Espirito para uma ruptura de auto suficiências. Isso é especialmente importante no caso das igrejas de tradição antiga, sempre tentadas de se refugiar na consciência de sua herança gloriosa. Estas igrejas não só têm necessidade uma da outra, mas têm, ao mesmo tempo, necessidade do serviço fraterno de outras comunidades cristãs para perceberem, ao vivo, os enrijecimentos, os deslocamentos de ênfase, as excrescências que sua longa história tornou inevitáveis..

... É aprendendo a amar, no conhecimento e no respeito das diversidades, que se faz a aprendizagem da unidade que Deus quer31.

Quando essa aprendizagem existe podem se esperar milagres de compreensão em debates que pareciam irreconciliáveis. Exemplo disso é o recente documento do diálogo anglicano-católico sobre o tema do ministério hierárquico e, em especial, do tão discutido e conflituoso ministério primacial da unidade.

${ }^{30}$ GROUPE DE DOMBES, Pour une réconciliation ..., Op.cit., p 51, citado por B. SESBOÜÉ, Op. cit., p. 301.

${ }^{31}$ J.-M. TILLARD, L'Église locale. Ecclésiologie de communion et catholicité, Paris: Cerf, 1995, pp. 379s. 


\section{"O dom da autoridade", exemplaridade de um diálogo}

Os co-presidentes da ARCIC, Comissão Internacional AnglicanoCatólica Romana, que elaborou o documento, intitulado "O dom da autoridade ${ }^{\prime 32}$, iniciam a apresentação com estas significativas palavras que mostram como, sem um longo caminho de diálogo, em atitude de conversão, não se poderia chegar a um entendimento sobre tema tão delicado como este, da autoridade na Igreja:

Há mais de trinta anos, iniciou-se uma busca intensa de unidade plena e palpável entre a Comunhão Anglicana e a igreja Católica Romana, no encontro histórico do Arcebispo Michael Ramsay com o Papa Paulo Vl, em Roma. A Comissão encarregada de preparar o diálogo reconheceu, como consta do Relatório de Malta, de 1968, que uma das "tarefas urgentes e importantes" seria examinar a questão da autoridade. De certa forma, essa questão está no âmago de nossas tristes divergências ${ }^{33}$.

O documento atual "é resultado de cinco anos de diálogo, de paciente escuta, estudo e oração", dizem-nos os co-presidentes na apresentação, e é oferecido ao estudo dos fiéis com autorização das autoridades de ambas as igrejas para a reflexão e discussão, prevendo que esse estudo suscitará "desafios a ambas as igrejas com relação à maneira como a autoridade é exercida nelas" ${ }^{\prime \prime 34}$.

A forma de tratar o tema difícil e controvertido da autoridade na Igreja é extremamente feliz. Fruto maduro da fecundidade do diálogo feito em espírito de oração e conversão, que procura compreender as razões do conflito e da discordância dos grupos em litígio em torno a esse ponto. Só reconhecendo as falhas no exercício da autoridade, pode o olhar da fé ser purificado para reconhecer nela um dom de Deus.

Há um vasto debate sobre a natureza e o exercicio da autoridade tanto nas igrejas quanto na sociedade em geral. Anglicanos e Católicos Romanos desejam dar testemunho, para as igrejas e para o mundo, de que a autoridade exercida de forma correta é um dom de Deus para trazer reconciliação e paz para a humanidade. O exercício da autoridade pode ser opressivo e destrutivo. $\mathrm{Na}$ verdade, frequientemente pode $5 \hat{e}-l o \mathrm{em}$ sociedades humanas $\mathfrak{e}$ até em igrejas, quando elas adotam certos padrōes de autoridade sem uma visão

32 COMISSÄO INTERNACIONAL ANGLICANO-CATÓlCA ROMANA, O Dom da Autoridade (Autoridade na Igreja III), São Paulo: Paulinas 1999.

${ }^{33} \mathrm{Ibidem}$, Prefácio, p. 11.

${ }^{34}$ Cf. Ibidem, Apresentação, p. 10. 
crítica. O exercício da autoridade no ministério de Jesus adquire características diferentes. $E$ em conformidade com o pensamento e o exemplo de Cristo que a Igreja é chamada a exercer a autoridade ${ }^{35}$.

A autoridade é um dom do Cristo à sua Igreja, porque é através dela que o sim de Deus à humanidade, dito no Cristo, e acolhido no Amém da obediência filial de Jesus, chega até nós. Por isso o tema da autoridade deve ser compreendido dentro do processo da Tradição, entendida não apenas como tradição de doutrinas, mas como o processo de recepção e comunicação da vida cristã que tem sua origem no Cristo, e que tem por sujeito todo o povo cristão.

\begin{abstract}
A Tradição é um canal do amor de Deus, que o torna acessivel na Igreja e no mundo hoje. Através dela, de uma geração a outra, e de um lugar a outro, a humanidade partilha a comunhão na Santíssima Trindade. Pelo processo da Tradição, a Igreja ministra a graça do Senhor Jesus Cristo e a koinonia do Espírito Santo (cf. 2 Cor 13,13). Portanto, a Tradição é essencial à economia da graça, do amor e da comunhão. Para aqueles cujos ouvidos não ouviram e cujos olhos não viram, o momento de receber o Evangelho salvador é uma experiência de iluminação, perdão, cura, libertação. Os que participam da comunhão do Evangelho não podem deixar de transmiti-lo aos outros, mesmo que isso signifique o martírio. A Tradição é um tesouro a ser recebido pelo povo de Deus e um dom a ser partilhado com toda a humanidade ${ }^{36}$.
\end{abstract}

Receber a Tradição é receber pelo dom do Espírito a Palavra de Deus, feita carne em Jesus Cristo e só pode ser feito em comunhão com todos os que crêem nele. A Tradição expressa a apostolicidade da Igreja. A sucessão apostólica, no duplo aspecto indicado acima, é o nexo concreto da Igreja com o evento da Palavra feita carne em Jesus de Nazaré.

A transmissño e a recepção da Tradição apostólica é um ato de comunhão pelo qual o Espirito une as igrejas locais de nossos dias com aquelas que as precederam na fé apostólica una. O processo da tradição acarreta a recepção e comunicação constante e contínua da Palavra revelada de Deus em muitas circunstâncias diversas e em tempos constantemente mutáveis. O "Amém" da Igreja à Tradição apostólica é fruto do Espirito que guia continuamente os discipulos para toda a verdade; ou seja, para Cristo, que é o caminho, a verdade e a vida (cf. Jo 16,$13 ; 14,6)^{37}$.

\footnotetext{
${ }^{35}$ COMISSÃO INTERNACIONAL ANGLICANA-CATÓLICA ROMANA, O Dom ..., Op. cit., $\mathrm{n}^{\circ} 5$.

${ }_{36}$ Idem, $\mathrm{n}^{\mathrm{o}} 15$

${ }^{37}$ Idem, $\mathrm{n}^{\circ} 16$.
} 
Três elementos constituem o processo da Tradição como ato de comunhão de toda a Igreja: a proclamação da Palavra, a celebração dos sacramentos e o testemunho da vida cristã. Os três envolvem a totalidade do povo cristão. Os três são, ao mesmo tempo, o "conteúdo da Tradição e o seu resultado ${ }^{\prime 38}$.

No interior da Tradição, as Escrituras ocupam um lugar único e normativo. A formação do Cânon das Escrituras foi parte integrante do processo da Tradição. A sua reta compreensão é necessária para que a Igreja permaneça fiel à Tradição e possa em cada circunstância da história, que nunca se repete, juntar seu "Amém" renovado ao Amém, dado uma vez por todas: o Amém de Jesus Cristo ao SIM salvador de Deus para a humanidade. O processo da Tradição é um ato de fidelidade e de liberdade. A Tradição deve ser recebida sempre de novo e de forma renovada. Não basta repetir as Escrituras. Elas devem tornar-se vida de um povo, chamado a ser testemunha e revelação, para o mundo, do Senhor ressuscitado.

A normatividade das Escrituras, sua fixação num Cânon, garante a fidelidade à Tradição, e, ao mesmo tempo, a liberdade da recepção, de forma que possa ser transmitida uma Vida e não apenas letra morta. $O$ processo de tradiçāo-recepção da vida cristã requer a co-responsabilidade de toda a Igreja, pastores e fiéis, e deve ser "assistido pela compreensão de estudiosos da Bỉblia e de teólogos e pela sabedoria dos sábios" ${ }^{\prime 39}$.

Diante de afirmações como estas, que refletem uma consciência comum aos cristãos de diversas comunhões cristãs, o católico pode reconhecer que muitos dos avanços na compreensão da Tradição se devem, em grande parte, aos cristãos oriundos da Reforma protestante. Se, como foi dito anteriormente, a divisão da Igreja não pode ser atribuída ao Espírito, pode se reconhecer que o Espírito aproveita a ferida da divisão para incentivar nos cristão uma escuta mais atenta da Palavra de Deus, levando a redescobrir aspectos esquecidos no processo da tradição-recepção da vida em plenitude que Cristo quer comunicar à sua Igreja. Aqui vale certamente a audácia da expressão litúrgica da Igreja na vigília pascal: O Felix culpa!

Pode-se imaginar quais seriam os rumos de uma Igreja adormecida na tranqüila crença de que bastasse a materialidade da sucessão histórica, com relação aos Apóstolos, para garantir a permanência na doutrina apostólica. Por outro lado, a multiplicação das igrejas que procuram encontrar na Bíblia a sua justificação, sem referência a essa

${ }^{38}$ ldem, $\mathrm{n}^{\circ} 18$.

${ }^{39}$ Idem, $\mathrm{n}^{\circ} 25$. 
sucessão, mostra que não basta a Bỉblia, fora da Tradição viva da Igreja, para manter a fidelidade à Palavra feita carne em Jesus Cristo e dada à Igreja como Palavra viva.

O Dom da Autoridade adverte com lucidez:

Dentro da Igreja, a memória do povo de Deus pode ser afetada ou mesmo deturpada pela limitação e pelo pecado humanos. Embora tendo recebido a promessa da assistência do Espírito Santo, de tempos em tempos, as igrejas esquecem alguns aspectos da Tradição apostólica, não conseguindo discernir a visão plena do reino de Deus à luz da qual procuramos seguir a Cristo. As igrejas sofrem quando algum elemento da comunhão eclesial foi esquecido, negligenciado ou deturpado. Recorrer à Tradição em uma nova situação é o meio pelo qual a revelação de Deus em Cristo é rememorada. Esse processo é assistido pela compreensão de estudiosos da Bíblia e de teólogos e pela sabedoria dos sábios. Assim, pode ocorrer uma re-descoberta de elementos que eram negligenciados e uma nova memória das promessas de Deus, levando a uma renovação do "Amém" da Igreja. Pode haver, também, um exame crítico do que tem sido recebido, porque algumas das formulações da Tradição passam a ser consideradas inadequadas ou até enganosas em um novo contexto. Podemos chamar todo esse processo de re-recepção"40.

É por isso que a Igreja tem a responsabilidade - lembra o documento - "de transmitir toda a Tradição", mesmo quando haja partes que num determinado momento possam parecer de difícil integração na vida e no culto. "Pode ser que o que significava muito para uma geração anterior venha a se tornar importante novamente no futuro, embora sua relevância não seja clara no presente" ${ }^{\prime 41}$.

Não há dúvida que, no momento da separação, as igrejas queriam manter a verdadeira Tradição. Mas se hoje reconhecem que devem buscar juntas elementos dessa Tradição, que por acaso possam ter sido esquecidos ou deturpados, é porque reconhecem que - devido ao pecado - houve uma insuficiente atenção aos apelos do Espírito, numa Igreja que deve confessar-se sempre "santa e pecadora".

Para limitar-nos apenas ao ponto nevrálgico do documento que estamos analisando: É muito alentador que num documento que busca um acordo doutrinal entre anglicanos e católicos se reconheça a necessidade de uma primazia universal, para que o dom da autoridade oferecido por Cristo à sua Igreja possa dar o fruto de um reencontro da unidade, contanto que o exercício da primazia seja conjugado com o exercício sinodal e colegial da autoridade episcopal.

${ }^{40}$ Idem, $\mathrm{n}^{\circ} 25$.

4) Idem, $\mathrm{n}^{\circ} 24$. 
O trabalho da Comissão tem tido como resultado um consenso suficiente sobre a primazia universal como um dom a ser compartilhado, até o ponto de poder propor que tal primazia seja oferecida e recebida mesmo antes de nossas igrejas atingirem uma comunhão plena. Tanto os Católicos Romanos quanto os Anglicanos cuidam para que esse ministério seja exercido em colegialidade e sinodalidade - um ministério de servus servorum Dei (Gregório, o Grande, citado em Ut Unum Sint, 88). Olhamos para uma primazia que, mesmo agora, irá ajudar a sustentar a diversidade legitima das tradiçoes, fortalecendo-as e salvaguardando-as em fidelidade ao Evangelho, e irá encorajar as igrejas em sua missão. Esse tipo de primazia já poderá auxiliar a Igreja na terra a ser a koinonia católica autêntica, na qual a unidade não diminui a diversidade, $e$ a diversidade não põe em perigo, mas estimula, a unidade. Será um sinal efetivo para todos os Cristãos de como tal dom de Deus constrói essa unidade para a qual Cristo rezou ${ }^{42}$.

Reconhece-se o valor e a necessidade de um ministério da unidade, dentro da diversidade das tradições, para fortalecer e salvaguardar a fidelidade ao evangelho.

Esse primaz universal irá exercer a liderança no mundo e também nas duas comunhôes, dirigindo-se a elas de forma profética. Promoverá o bem comum sem a coaçāo de interesses setoriais, e oferecerá um ministério de ensino contínuo e próprio, principalmente ao considerar questóes teológicas e morais difíceis. Uma primazia universal nesse estilo irá acolher e proteger a investigaçäo teológica e outras formas de busca da verdade, para que seus resultados possam enriquecer $e$ fortalecer a sabedoria humana e a fé da Igreja. Tal primazia universal poderia unir as igrejas em vários tipos de consulta e discussão ${ }^{43}$.

Evidentemente que não se trata sem mais da submissão da igreja anglicana ao autoridade primacial do Papa da forma como atualmente é exercida. Pré-supõe-se um caminho de conversão de ambos parceiros do diálogo para chegar aos consensos expressos no documento. Uma abertura por parte da igreja anglicana de reencontrar o exercício do ministério da primazia universal do Bispo de Roma, sob certas condições. Por parte dos católicos a abertura a reencontrar um exercício da primazia que, despojando- se de formas do passado, inaceitáveis para outras confissões cristãs, responda ao que Cristo quis ao doar à Igreja um ministério da unidade. Já o Papa tinha manifestado na Encíclica lit unum sint esta abertura.

Aquilo que diz respeito à unidade de todas as Comunidades cristãs, entra obviamente no âmbito das preocupaçōes do primado. Como Bispo de Roma, sei bem - e confirmei-o na presente Carta enciclica - que a comunhão plena $e$ visivel de todas as Comunidades, nas quais em

${ }^{42}$ Idem, $\mathrm{n}^{\circ} 60$

${ }^{43}$ Idem, $\mathrm{n}^{\circ} 61$. 
virtude da fidelidade de Deus habita o seu Espírito, é o desejo ardente de Cristo. Estou convicto de ter a este propósito uma responsabilidade particular, sobretudo quando constato a aspiração ecumênica da maior parte das Comunidades cristãs, e quando ouço a solicitação que me é dirigida para encontrar uma forma de exercício do primado que, sem renunciar de modo algum ao que é essencial da sua missão, se abra a uma situação nova. Durante um milênio, os cristãos estiveram unidos pela "fraterna comunhão da fé e da vida sacramental. Quando entre eles surgiam dissensões acerca da fé ou da disciplina, era a Sé de Roma quem, de comum acordo, as resolvia» ${ }^{44}$.

$\mathrm{O}$ documento $\mathrm{O}$ dom da Autoridade expressa, de maneira precisa, não só a abertura, mas também o desejo de uma re-recepção do exercício do ministério da primazia universal:

Uma experiência de primazia universal desse tipo confirmaria duas conclusões especificas a que chegamos:

de que os Anglicanos estão abertos e desejosos de uma recuperação $e$ re-recepção, sob certas condições claras, do exercício da primazia universal pelo Bispo de Roma;

de que os Católicos Romanos estão abertos e desejosos de uma rerecepção do exercício da primazia pelo Bispo de Roma e da oferta desse ministério para toda a Igreja de Deus ${ }^{45}$.

Para que seja possível essa re-recepção do exercício da Primazia, o seu exercício deverá ser concebido colegialmente no contexto da sinodalidade (derivado de syn-hodos, que significa "caminho comum"), ou seja, do chamado de todos os fiéis e de todas as igrejas a caminhar em Cristo. A sinodalidade "expressa a vocação do povo de Deus, como povo do Caminho (cf. At 9.2) para viver, trabalhar e andar juntos em Cristo, que é o Caminho (cf. Jo 14.6)" ${ }^{\prime \prime 4}$. Isto está na linha da eclesiologia de comunhão presente nos textos do Vaticano II, mas, certamente, continua sendo um desafio para a Igreja até se tornar prática comum.

Se for possível esperar o restabelecimento da comunhão entre as diversas confissões cristãs deverá ser pelo caminho de "uma diversidade reconciliada" ou uma "unidade plural". Isto implica uma maneira de conceber e viver a Igreja como comunhão de comunidades diversificadas. É a experiência de comunhão, de colegialidade, inspirada pelo Espírito Santo, que bispos e teólogos reunidos no Concilio Vaticano II sonharam poder se tornar realidade, mas que hoje está provavelmente mais longe do horizonte das expectativas do que a quarenta anos atrás.

\footnotetext{
${ }^{4}$ Ut Unum sint, $\mathrm{n}^{\circ} 95, \S 2$.

${ }^{45}$ COMISSÃO INTERNACIONAL ANGLICANO-CATÓlICA ROMANA, O Dom...,Op. cit., $\mathrm{n}^{\circ} 62$.

${ }^{46}$ Idem, $\mathrm{n}^{\circ} 34$.
} 
Como imaginar uma comunhão de igrejas cristãs reconciliadas na sua diversidade, na unidade plural da única Igreja de Cristo, quando mesmo dentro da igreja católica romana o poder decisório dos Bispos nas diversas Dioceses e das Conferências episcopais é mínimo diante da centralização do poder decisório na Cúria romana?

Quando se pensa, por outro lado, na participação ativa do povo de Deus, na contribuição real do "sensus fidei", descrita no documento $O$ Dom da Autoridade como "capacidade ativa de discernimento espiritual" dos fiéis, e como "intuição formada pelo culto divino e pela vida em comunhão", é fácil prever o longo caminho a ser andado para que todo povo de Deus exerça efetivamente a sua participação ativa no processo da Tradição.

Através do sensus fidelium, resultado do comum acordo do sensus fidei dos fiéis, "o corpo todo contribui para, recebe de, e guarda como um tesouro o ministério daqueles membros da comunidade que exercem a episcopé velando pela memória viva da Igreja ${ }^{\prime \prime 7}$ na recepção e comunicação ativa da Tradição, ou seja, da vida recebida de Cristo, afirma-se no documento. E mais adiante: "O exercício da autoridade de ensinar na Igreja, principalmente em situações desafiadoras, requer a participação de todo o corpo de fiéis em suas formas diversificadas, e não apenas daqueles incumbidos do ministério da memória. Nessa participação, o sensus fidelium está operando. Como é a fidelidade de todo o povo de Deus que está em jogo, a recepção dos ensinamentos é parte integral do processo" ${ }^{\prime \prime 4}$.

Esta participação do povo de Deus no processo da Tradição é um direito e uma responsabilidade. Para que o sensus fidelium seja legítimo deve fundamentar-se no sensus fidei, quer dizer, deve proceder de uma fé esclarecida e não apenas de um sentimento religioso qualquer, que pode ter suas raízes em formas de piedade ainda pagãs, e não transfiguradas pela novidade do Evangelho. Requer-se para tanto uma formação catequética que dê origem a uma fé fundamentada em Deus $(1 \mathrm{Pe} 1,21)$ e que saiba "dar razão da sua esperança" $(1 \mathrm{Pe} 3,15)$. Evidentemente isto não é tarefa para um dia. É mais fácil prometer "graças", soluções imediatas para as carências do povo, e assim encher os templos, do que educar na responsabilidade eclesial de discernir a cada momento, perante os grandes desafios da história, qual é a vontade de Deus num mundo redimido pela cruz do Cristo.

A situação das igrejas na Europa deveria alertar aqueles pastores que se servem das carências dos pobres do Terceiro Mundo para mantêlos em volta de si, na ilusão de estar anunciando o Evangelho. Fe-

\footnotetext{
${ }^{47}$ Idem, $\mathrm{n}^{\circ} 29$.

${ }^{48}$ Idem, $\mathrm{n}^{\circ} 43$.
} 
nômenos como o da igreja Universal do Reino de Deus e de alguns grupos pentecostais, em que atitudes pastorais do "catolicismo" criticado pela Reforma são levadas até o extremo da caricatura, ao mesmo tempo em que tais igrejas se apresentam como "movimento evangélico", em cruzada combativa frente à igreja católica, deveriam alertar os cristãos: reunir multidões com motivações religiosas não pode ser critério de autenticidade do anúncio do Evangelho de Jesus Cristo.

Nessas caricaturas vivas da Igreja de Jesus Cristo, a obediência à autoridade do ministério, se torna dependência de um poder sagrado, controlado pelo ministro, que precisa ser comprado ou conquistado pelo fiel a troco de orações, rezas fortes, ofertas ...

Voltar a receber o serviço ministerial, em todos os seus degraus, como um dom, que possibilita a acolhida agradecida do sim de Deus a todas as suas promessas em Jesus Cristo, para que toda a Igreja seja povo profético e sacerdotal para serviço do Reino, exige uma conversão em todos os níveis da Igreja.

Esta conversão deveria retomar o sopro do Espírito que tornou possível o Concílio Vaticano II, concebido não de forma estática, mas como ele pretendia ser, ponto de partida para uma renovação que deveria continuar ao ritmo dos tempos. Terá que exorcizar a tentação de voltar atrás, com a ilusão de que isso impediria a perda de "adeptos", e acreditar no evangelho, "força de Deus para a salvação de todo aquele que crê, primeiro do judeu e também do grego; visto que a justiça de Deus se revela no evangelho, de fé em fé, como está escrito: O justo viverá por fé" (Rm 1, 16-17). Fidelidade ao Evangelho é a única forma de garantir, a longo prazo, o seu poder de salvação e de atração para o ser humano.

\section{Outro documento exemplar: Maria no desígnio de Deus e na comunhão dos santos}

Após mais de cinqüenta anos de paciente trabalho ecumênico no domínio doutrinal, e após seunúltimo documento apelando à conversão das igrejas ${ }^{49}$, o grupo de Dombes julgou que uma audácia lhe era já possível: abordar o tema da Virgem Maria"50. Com estas palavras é introduzido o documento sobre este tema tão marcado historicamente por preconceitos e ressentimentos mútuos entre católicos e protestan-

${ }^{49}$ GRUPO DE DOMBES, Pour la conversion des Églises, Paris: Centurion, 1991.

${ }^{50}$ GRUPO DE DOMBES, Marie dans le dessein de Dieu et la communion des saints. Dans l'histoire et l'Écriture. Controverse et conversion. Paris: Bayard / Centurion, 1999, p. 17. 
tes, e por resistências, no nível afetivo, que bloqueiam o exame sereno dos argumentos teológicos.

Os limites deste artigo não permitem tratar este assunto tão relevante com o cuidado que ele merece. Uma vez que o documento está em vias de tradução e será publicado proximamente pelas Edições Loyola, esta revista poderá nessa ocasião tratar o tema. Agora queremos apresentá-lo como mais um exemplo de que a conversão das igrejas é o único caminho que pode apressar o dia em que muitos dos cristãos, hoje divididos, possam celebrar juntos a Eucaristia na comunhão dos santos entre os quais o primeiro lugar corresponde à Virgem Maria.

Apenas como exemplo, tomemos o aspecto controvertido da invocação de Maria e dos santos, no qual persistem diferenças que não podem ser ignoradas, na prática das igrejas. Os católicos louvam e invocam a intercessão de Maria e dos santos. Os reformados se recusam a admitir a legitimidade da oração de intercessão dirigida a Maria e aos santos.

Só um diálogo em atitude de conversão que procure ver as razões do interlocutor pode mostrar que as duas práticas expressam substancialmente a mesma fé e que cada uma delas pode ajudar a corrigir possíveis desvios da outra. A razão alegada pelos protestantes para se opor ao pedido de intercessão $a$ Maria e aos santos é uma verdade que os católicos devem também aceitar. Como diz o documento de Dombes sobre Maria: "no rigor dos termos, segundo a tradição antiga não se ora a Maria nem aos santos, porque a oração, forma de adoração, só pode ser dirigida a Deus. Um uso porém mais amplo do termo, embora teologicamente impróprio, difundiu a expressão da oração a Maria e aos santos" ${ }^{\prime \prime}$.

O que este termo "impróprio" pode significar? Os católicos invocam Maria para que ela interceda a Deus em nosso favor. A invocação é, em primeiro lugar, louvor a Deus pela graça feita a Maria e em comunhão com ela e com todos os santos, os que estão na terra e os que já estão na glória do céu. O próprio Lutero podia afirmar: “Na comunhão da Igreja universal, com os anjos e todo o exército celeste, em comum alegria nós engrandecemos teu nome glorioso: Santo, santo, Santo..." ${ }^{52}$. Esta invocação é expressão da comunhão eclesial, não abolida pela morte, no louvor ao Pai, pelo Filho, no Espírito de que toda a tradição litúrgica dá testemunho.

\footnotetext{
${ }^{51}$ Ibidem, n² 276, p. 143.

${ }^{52}$ M. LUTERO, Sermão sobre a Ave Maria, 1523; WA, t. XI, p. 61. Citado em GRUPO

DE DOMBES, Marie,..., Op.cit. p. 146.
} 
O louvor a Maria corresponde ao convite do Magnificat: "Todas as gerações me chamarão bem-aventurada" (Lc 1,48) e está presente nos grandes Reformadores, embora Lutero reagisse violentamente contra as deformações do culto mariano na igreja católica do seu tempo.

$\mathrm{Na}$ igreja católica, o magistério teve sempre que intervir para evitar que se confundisse a "veneração" - o louvor, a honra, o carinho devido a Maria e aos santos com a adoração que é devida só a Deus. Essa veneração se insere no louvor a Deus com Maria e todos os santos pela obra da salvação em Jesus Cristo e equivale a louvar em Maria a ação da graça divina e dar graças a Deus por sua resposta exemplar.

A questão da legitimidade da oração de intercessão, dirigida a Maria e aos santos, só pode ser respondida dentro desses parâmetros. Para o católico não pode ser mais do que uma oração dirigida a Deus, que é o único que pode responder à oração do fiel conforme o seu beneplácito. A invocação da intercessão de Maria e dos santos não é mais do que a explicitação do lugar donde brota toda oração cristã que é a comunhão eclesial com o Cristo, cabeça da Igreja, que intercede por nós ao Pai na unidade do Espírito. É uma forma popular, humana, de expressar essa comunhão.

É fácil ver que as formas que a invocação aos santos podem tomar, na religiosidade popular, correm o perigo de se afastar desta concepção cristã da oração, até o ponto extremo de fazer dos santos quase pequenas divindades, capazes de administrar por sua conta os favores celestes.

Reagindo a estes abusos, e para evitar todo mal-entendido, os reformadores recusam todo pedido de intercessão dirigido a Maria e aos santos, para defender a verdade central do cristianismo, da absoluta gratuidade da salvação em Cristo e da mediação única de Jesus Cristo. Certamente com esta recusa não estão negando que toda oração é feita em comunhão com toda a Igreja, terrestre e celeste, em comunhão com Maria e com os santos. Concordam, por outro lado com os católicos, em que conforme as Escrituras é preciso venerar, ou seja, amar, respeitar, honrar a Virgem Maria e todos os santos e louvar a Deus pelas maravilhas de Deus neles. Estão igualmente de acordo em considerar os santos, e de maneira especial Maria, como um exemplo que deve ser imitado em particular juntando-nos à sua oração.

São duas formas de orar. A tradição protestante recusa a Maria todo papel de intercessão, para evitar que se pense em alguma mediação que se possa acrescentar à única mediação do Cristo, enquanto os católicos, seguindo uma tradição mais condescendente com as formas de devoção popular, se confiam à sua intercessão materna dizendo-lhe 
quotidianamente: "Rogai por nós pecadores", como jeito de expressar a comunhão eclesial com Maria na oração apresentada ao Pai pelo único Mediador.

O documento de Dombes lança uma pergunta corajosa:

Teremos que parar nesta constatação? Nesta oposição? A veneração não pode conter para os protestantes a palavra Angélica da Ave Maria ou uma palavra de irmã, como "És bendita entre todas as mulheres", tiradas ambas da Escritura?

A intercessão pode ser concebida de outra forma que não seja parte integrante da comunhão dos santos da terra e do céu, dos humanos $e$ do Deus trinitário, inserindo-se na eterna intercessão do Filho junto ao Pai, à qual responde a intercessão do Espirito em nós, pecadores $e$ justificados? Longe de ser uma marca de distância e de diferença, não é antes o sinal de uma comunhão e uma partilha. Longe de ser privada $e$ exclusiva, näo se abre ela sobre o mundo tão amado por Deus e sobre a criação inteira confiados à responsabilidade daqueles que foram escolhidos para servir diante da sua face, a comefar pela mãe do Salvador, a bem-aventurada Virgem Maria? A oração a Maria e por Maria continua sendo assim uma oração como a oraçāo de Maria e com Maria. Ela não apagará as distinções, mas não as erigirá em separaçōes ${ }^{53}$.

A conclusão do documento sobre este ponto é que as duas formas de piedade poderiam conviver lado a lado e não seriam causa de divisão, contanto que haja uma vigilância teológica e pastoral para que se evitem do lado católico os exageros e deformações da piedade mariana e da devoção aos santos e do lado protestante as restrições à legítima "veneração" de Maria, que historicamente aconteceram por reação defronte aos exageros católicos. E quem pode negar que a convivência destas duas formas de piedade seja benéfica para a procura fraterna da pureza da fé?

É claro que este é apenas um ponto do tema de Maria tratado no documento de Dombes. Depois de tratar todos os aspetos envolvidos na questão de Maria, conclui o grupo misto:

Podemos pois propor nossa conclusão: enquanto membros do Grupo de Dombes, levando em conta as propostas de conversão que encerram nosso percurso, nós não consideramos mais como separadoras as divergências levantadas. Ao termo de nossa reflexão - histórica, biblica $e$ doutrinal - não encontramos já incompatibilidades irredutiveis, apesar de existirem reais divergências teológicas e práticas.

$O$ que nos transmite o símbolo da fé é unanimemente recebido: cle ensina que Jesus "concebido pelo Espirito santo, nasceu da Virgem

${ }^{53}$ GRUPO DE DOMBES, Marie,..., Op. cit.., $\mathrm{n}^{\circ} 287$, p. 147. 
Maria». Nós temos recebido também o testemunho da Escritura. Nós temos considerado Maria no coração do desenvolvimento da vida do Cristo e do seu Corpo que é a Igreja. Esta consideração é legítima, porque está fundada no artigo de fé inserido no Símbolo dos Apóstolos sob o nome de "comunhão dos santos»".

O documento termina com estas palavras: "Confiamos agora ao leitor, à sua atenção e à sua oração, a descoberta deste caminho ao qual é convidado a se associar" ${ }^{\prime 5}$. Trata-se de um caminho de conversão. Anteriormente todo o capítulo quarto, intitulado "Para a conversão das igrejas" sugeria para cada uma das igrejas os pontos fundamentais dessa conversão: conversão de atitude, conversão doutrinal e conversão do culto mariano. O capítulo começava com estas palavras:

Nosso percurso histórico nos mostrou que a divisão entre nós aparece no momento em que Maria é isolada ao mesmo tempo do Cristo e da comunhão dos santos, e em que a devoção se concentra exageradamente sobre ela. Assim, do lado católico, a «mariologia» tem sido indevidamente separada da cristologia e da eclesiologia. Por isso a decisão do Vaticano II, inserindo o texto sobre Maria na Constituição sobre a Igreja é um gesto de grande significação para nossa reconciliação ecumênica. A eclesiologia permite reintegrar Maria no povo de Deus. Do lado protestante, se reconhece que uma reta confissão do Cristo exige uma palavra sobre Maria, em nome mesmo da encarnação ${ }^{56}$.

Não é o propósito deste artigo entrar em detalhes a respeito desses caminhos de conversão. O testemunho exemplar do grupo de Dombes foi trazido aqui para confirmar o que já foi dito repetidamente ao longo destas páginas. Sem um processo de conversão, que deve atingir as igrejas em todos os seus niveis, a unidade da Igreja de Jesus Cristo não sairá dos desejos utópicos. O movimento ecumênico não progredirá.

Esse processo de conversão, que permita a descoberta de caminhos que conduzam à unidade da Igreja de Jesus Cristo, deverá realizar-se no âmbito das igrejas locais. Como dizia Sesboüé, falando da proposta de reconhecimento mútuo de ministérios, ela só poderia ser feita num primeiro momento em âmbito local.

Isto nos conduz ao ponto nevrálgico da questão ecumênica, com o qual queremos concluir este ensaio: a prática da eclesiologia de comunhão presente nos documentos do Vaticano II e seu progressivo desenvolvimento.

${ }^{54}$ Ibidem, $\mathrm{n}^{\circ} 335$, p. 170

55 Ibidem, $\mathrm{n}^{\circ} 338$, p. 171

56 Ibidem, $\mathrm{n}^{\circ} 289$, p. 1149 . 


\section{Igreja local, eclesiologia de comunhão e catolicidade}

Este é o título da obra de J.-M. Tillard, citada anteriormente ${ }^{57}$. E não é por acaso que o terceiro estudo sobre a Eclesiologia de comunhão desenvolva mais extensamente o tema da igreja local, já presente nos estudos anteriores Église d'Églises e Chair de l'Église, chair de Christ. Neste último, o autor via na Eucaristia a fonte da eclesiologia de comunhão. É precisamente na celebração da eucaristia, que só pode ser realizada em âmbito local, que a Igreja de Cristo, toda inteira, se torna presente como corpo indiviso do Senhor. Escrevia ele:

É na eucaristia que podem ser reencontrados os caminhos de uma pluralidade reconciliada, porque é aí que a Igreja encontra a sua identidade, encoberta quiçá pela poeira acumulada pelas diversas concretizações sociológicas do seu caminhar histórico. A fé não se exprime da mesma forma em Alexandria e em Antioquia. A Liturgia não tem as mesmas formas em Roma e em Kinshasa. Bernardo não pensa como Abelardo, Ramtramno como Pascásio Radberto, Tomás de Aquino como Boaventura..

Mas por outra parte, um membro de Cristo, uma igreja local, não saberia abismar-se totalmente na sua 'diferença', fazendo dela o essencial da sua experiência cristã....Por causa da sua origem, a assembléia pascal operada por Cristo, a Igreja se recusa à atomização da sua textura. Ela contesta a confusão entre afirmação da 'diferença' e independência" ${ }^{\prime 58}$.

Compreendendo-se como Corpo do Cristo, mediador universal da salvação, nascendo constantemente do Corpo sacramental do Cristo, entregue em favor da vida do mundo, a Igreja pode receber dele os caminhos da unidade que Deus quer.

Celebrar a Eucaristia deveria significar fazer a experiência do Corpo de Cristo ferido. Porque Cristo celebra sempre com toda a Igreja, e esta Igreja está dividida. A ferida só será curada no dia em que todas as igrejas se sentirem reconciliadas em torno à mesma mesa. A igreja local, ao celebrar a Eucaristia, deve deixar-se interpelar por Cristo e ser levada a interrogar-se sobre si mesma. Cientes de que ao recordar isto pisamos um terreno propício para suscitar desconfianças, medos, rivalidades, passamos a palavra a uma voz autorizada, com uma experiência de diálogo ecumênico sustentado durante décadas:

\footnotetext{
${ }^{57}$ Cf. nota 31 .

${ }^{58}$ J.-M. TILLARD, Chair de l'Église, chair du Christ, Aux sources de l'ecclésiologie de communion, Paris: Cerf, 1992, p, 23. A primeira obra em que o autor trata deste assunto é: Église d'Églises: La ecclésiologie de communion, Paris: Cerf, p. 1087.
} 
Numa época em que renascem os confessionalismos é essencial agir de forma que as comunidades de batizados não se percebam como grupos ciumentos de sua identidade confessional, mas saibam perceber no outro uma palavra de Deus que interpela, inquieta, perturba e finalmente leva a interrogar-se sobre si mesmo. Cada comunidade se torna assim para as outras como a "memória» da dimensão evangélica que a caracteriza. Ela, por sua vez, pode ver nas outras os traços evangélicos que a ajudam a tomar consciência de seu próprio limite, da sua pobreza ${ }^{59}$.

Tillard conclui este parágrafo com a afirmação, nascida certamente da própria experiência,

de que o diálogo ecumênico é instrumento do Espírito para uma ruptura de auto-suficiências.

O horizonte destes encontros da igreja local com outras comunidades cristãs que convivem lado a lado não saberia ser outro que a caridade. Retomando a fórmula que definiu as relações entre Paulo VI $e$ Atenágoras $I$, pode se dizer que o batismo comum exige e torna possivel o "diálogo da caridade". Isso vem ao encontro da experiência da qual dão testemunho a maior parte daqueles e daquelas que estiveram intimamente implicados no trabalho ecumênico. Quebrando o isolamento, suscitando um conhecimento mútuo, o encontro ecumênico "fagocita" lentamente as desconfianças, as prevenções, os ódios tradicionais.

Aprendendo a amar-se no conhecimento e no respeito das diversidades, se faz o aprendizado da unidade que Deus quer" ${ }^{60}$.

Este aprendizado, testemunhado por aqueles que durante longas décadas, persistindo no diálogo ecumênico, alma do Concílio Vaticano II, tem que ser feito pelas igrejas como um todo, e o lugar para isso é a igreja local. Tillard afirma que já é hora de institucionalizar a presença ativa de membros de outras comunidades nas reuniões da igreja local.

A razão de privilegiar a igreja local como lugar por excelência do progresso do caminhar ecumênico não nasce apenas de conveniências táticas. A razão é teológica. É na igreja local que a universalidade da Igreja de Jesus Cristo se realiza. Como mostra o relato de Pentecostes dos Atos dos Apóstolos, a Igreja apostólica nasce, como Igreja de Deus, aberta a todos os povos e línguas, num lugar determinado, em Jerusalém. Nasce no mesmo dia em que se celebra o memorial da promulgação da Lei no Sinai, destinada a todos os povos, conforme a cons-

${ }^{59}$ J.-M. TILLARD, L'Église locale..., Op. cit.. p. 379.

${ }^{60}$ Ibidem. p, 380. 
ciência de muitos grupos judeus, nessa época ${ }^{61}$. Realiza-se pelo poder do Espírito, o desígnio divino de reunir todos os povos.

Porque nasce da assembléia de Pentecostes (memorial da assembléia do Deserto), como cumprimento daquilo para o qual tendia a reunião do Qahal, a igreja de Jerusalém nasce pois, imediatamente, católica. Porque ela carrega a plenitude, a integralidade, o katholu do dom de Deus. Ela é assim a comunidade na qual a economia divina atinge seu tempo (kairos) de plenitude ${ }^{62}$.

A Igreja nasce assim católica num lugar. No lugar onde Deus quis que seu Filho morresse e ressuscitasse. Nasce na cidade santa, em torno aos Doze, que simbolizam as doze tribos de Israel. Por isso é a Igreja de Deus. Mais tarde, como resultado da missão apostólica, ela se tornará presente em outros lugares. Em Antioquia, em Éfeso, em Corinto... Não como parte ou apêndice da igreja de Jerusalém, mas como a Igreja de Deus naqueles lugares, em comunhão com a igreja apostólica de Jerusalém.

A Igreja, como o Cristo, deve encarnar-se num lugar, marcada pelas peculiaridades originadas duma concreta situação geográfica e cultural, mas sem ser por elas isolada da comunhão com as outras igrejas, senão aberta à universalidade da convocação de Deus. É precisamente por isso que a tensão entre pluralidade e unidade da Igreja de Jesus Cristo deve encontrar em cada igreja local, responsável pela catolicidade da resposta à convocação de Deus, os caminhos da reconciliação.

Sendo a eucaristia a "reunião" que faz com que a igreja local seja a Igreja de Deus (toda ela, na medida em que está em comunhão com a Igreja apostólica) num lugar determinado, é claro que as normas sobre "hospitalidade eucarística" e mesmo sobre "intercomunhão eucarística" carecem de uma revisão, que não poderá ser feita de repente no âmbito da Igreja universal, mas deverá nascer e crescer ao ritmo dos reais progressos da caminhada ecumênica das igrejas locais $^{63}$.

Isto leva à conclusão de que o diálogo ecumênico só poderá progredir e abrir caminhos concretos rumo à manifestação da unidade da Igreja que Cristo quer, na medida em que crescer a prática da eclesiologia de comunhão, da qual podemos dizer ser também a alma

61 Ver o desenvolvimento disto em ibidem, pp. $33 \mathrm{~s}$.

62 Ibidem, p. 34.

${ }^{63}$ Tive a alegria de tratar este tema, juntamente com meus irmãos de outras confissões cristãs, em encontro recente organizado pela CONIC. Cf. Hospitalidade Eucarística, Subsídios elaborados pelo Seminário Bilateral Misto Católico Romano - Evangélico Luterano. Porto Alegre: Edipucrs, 2000. 
do Concilio Vaticano II. Na medida, também, em que o povo de Deus, todo ele, seja educado na responsabilidade comum pela fidelidade à Palavra de Deus, na comunhão da fé apostólica. Numa Igreja dividida, esta fidelidade requer uma solicitude por todas as igrejas, porque os caminho de uma pluralidade reconciliada são responsabilidade de todo o povo cristão.

Olhando para o panorama atual das práticas eclesiais, salta à vista que o campo de reeducação do povo cristão é amplo e exigente. O leitor que estiver disposto a deixar-se conduzir pelo Espírito à conversão para a Unidade da Igreja de Jesus Cristo, saberá tirar as consequêencias. E isto vale para as igrejas. Não se trata apenas da conversão dos indivíduos às igrejas, mas da conversão das igrejas ao Evangelho ${ }^{64}$, para que possa realizar-se a petição de Cristo: Ut unum sint. E todo cristão deve sentir-se responsável por esta conversão das igrejas e ser educado para tanto.

Juan Antonio Ruiz de Gopegui SJ, doutorou-se em Teologia pela Pontifícia Universidade Cregoriana - Roma, em 1976. É professor de Teologia do Centro de Estudos Stperiores da Companhia de Jesus em Belo Horizonte. Entre outras obras publicou: Conhecimento de Deus e Evangelização, São Paulo: Loyola, 1977.

Endereço: Rua José Lins do Rego, 337 - Tupi

31842-350 Beio Horizonte -- MG

e-mail: ruizgopegui@brfree.com.br

in Isto é magnificamente tratado no Documento do grupo de Dombes, anteriormente citado: Pour la conzersion des Églises. O leitor poderá encontrá-lo em La Documentation Catholique' 88 (1981) 733-753 e 781-790. 